\title{
A study of anthropogenic, marine and other influences upon water chemistry in Hong Kong rivers
}

\author{
G. W. S. Wong \& M. R. Peart \\ Department of Geography, The University of Hong Kong, Hong Kong
}

\begin{abstract}
A six-year river data water quality set obtained by the Hong Kong Environmental Protection Department (HKEPD) at 82 monitoring sites are used to study, at the regional scale, the spatial controls and influences upon water chemistry in HK rivers. Univariate statistics and factor analysis of the elements have been applied to analyze 27 determinands of surface water quality $(\mathrm{pH}$, water temperature (Temp), flow, Salinity (Sal), Total Solids (TS), Conductivity (COND), Cl, TOC, $\mathrm{BOD}_{5}, \mathrm{COD}, \mathrm{DOmg} / \mathrm{L}, \mathrm{DO} \%, \mathrm{NH} 4, \mathrm{NO} 2, \mathrm{NO} 3, \mathrm{TKN}, \mathrm{TP}$, $\mathrm{PO} 4, \mathrm{Al}, \mathrm{Fe}, \mathrm{Zn}, \mathrm{Mn}, \mathrm{Pb}, \mathrm{Cd}, \mathrm{Cr}, \mathrm{Cu}, \mathrm{Ni})$. The statistical results show that nutrients, aggregate organics and metals have greater variation than physical parameters which are less influenced by anthropogenic factors. These determinands can also be explained by four principle factors, representing nutrient and organic contamination, marine influences and heavy metal contamination. Finally, the local rivers can be classified into four groups, based on the factor scores derived from the factor analysis. These results may contribute to the improvement of landuse planning and sewerage design in the future.

Keywords: river-water chemistry; marine influence, nutrient and heavy metal contamination.
\end{abstract}

\section{Introduction}

It is well recognized that the water-quality determinands in rivers can reflect many factors and processes functioning in the drainage basins and catchment systems, such as atmospheric deposition, soil erosion, weathering of crustal minerals, biomass characteristics and anthropogenic inputs (Berner and Berner 
[2], Markrich and Brown [11], Meybeck [12]). Furthermore, previous studies have shown that the regional monitoring and research of water-quality elements in rivers can contribute to the reduction of river contamination, the formulation of water resources management programs, the design of effective monitoring networks and the investigation of environmental effects brought by socioeconomic components, such as the change of landuse (Gueguen et al. [7]; Meybeck [12], Pekey et al. [14]). Therefore, river research and monitoring in a regional context is common in most countries, such as the Joint Danube Survey (JDS) in Europe (Woitke et al. [17]).

Hong Kong is a metropolitan city with a high population density and intense land competition. Although more than a hundred of streams and rivers are observed in this small area $\left(1102 \mathrm{~km}^{2}\right)$, river research at the regional scale is rare, except three pieces of research conducted by Binnie \& Consultant Engineers in 1974, the Environmental Protection Agency in 1981 and Li et al. [10]. However, the researchers ignored most water-quality determinands except organic and nutrient content. Also, these studies did not apply multivariate statistical techniques to investigate the spatial variation and the factors governing the relationship/association of these elements.

In this regard, the primary aim of this study is to examine the interrelationship between water-quality determinands and to identify the spatial controls upon water quality at the regional scale. This study helps to fill in the research gap of a regional river study in Hong Kong, and provide a basis for contamination- abatement and may help formulate a better management plan for the local river environment.

\section{Materials and methods}

\subsection{Study sites}

Hong Kong (HK, latitude: $22^{\circ} 9^{\prime} \sim 22^{\circ} 37^{\prime} \mathrm{N}$; longitude: $113^{\circ} 52^{\prime} \sim 114^{\circ} 30^{\prime} \mathrm{E}$ ) is located at the South East coast of China in Guangdong Province. It consists of Hong Kong Island, Kowloon Peninsula, the New Territories, and 235 islands. Its population is over 6.8 million and the land area is $1102 \mathrm{~km}^{2}$. The geology in HK is straightforward as it is dominated by volcanic rocks and granites. About $20 \%$ of total land area is developed while the remaining $80 \%$ is steep hillsides covered with secondary grasslands and shrublands (Lee et al. [9]). Major rivers in HK number only 10, but there are around 600 small streams or creeks. Most rivers and streams originate in the mountains and hills, then flow through the built-up area and/or alluvial plain in the North and West. There is no natural lake in HK, but some man-made storage reservoirs exist (UNESCAP [16]).

In 2003, more than half of the monitored rivers were recorded as 'excellent' or 'good' in terms of the Water Quality Index (EPD [6]). However, the mainstreams in HK are still under the pressure of channelisation (DSD [4]), sewage disposal (Sin et al. [15], sedimentation (Peart [13]) as well as different kinds of contamination. 


\subsection{Description of dataset}

The Hong Kong Environmental Protection Department (HKEPD) has carried out a river monitoring programme since 1986, but the dataset in this research covers the $1998-2003$ period (6-years), which are available on the EPD's website. For each of the sites, samples are normally collected on a monthly-basis, so the sampling number is 72 (except two stations with $N=56$ )

To date, the HKEPD's dataset potentially contains 46 water-quality determinands for each sample. Owing to the problem of missing values, only 27 determinands, each of which have at least $30 \%$ of total possible observations, are selected for use in this study. These determinands include physical properties, aggregate organics, nutrients and total fraction heavy metals. The list of these determinands is given in table 1 , and the details of field and analytical methods are provided in the HKEPD's annual report (EPD [6]).

\subsection{Statistical treatment of data}

Univariate statistics (arithmetic mean, geometric mean, standard deviation, relative standard deviation) are calculated for each variable. For the multivariate analyses, the geometric mean is used for minimizing the influences of extreme outliers (Pekey et al. [14]).

The dataset has also been standardized using Z-score transformation, so as to remove the scaling effects among different determinands and to fulfill the assumption of cluster and factor analysis (Helsel and Hirsch [8]).

Before the Q-mode factor analysis was carried out, the dataset were examined by two tests: the Karser-Meyer-Olkin Measure (KMO) of Sampling Adequacy and Barlett's Test of Sphericity. Then, varimax rotation and regression factor scores are conducted on the factor analysis results.

\section{Results and discussion}

\subsection{General characteristics of water-quality determinands in HK}

The summary descriptive statistics (arithmetic and geometric means) of waterquality determinands for the 82 monitoring stations are given in table 1. For nutrients, the total average of $\mathrm{PO}_{4}, \mathrm{NO} 3$, and $\mathrm{NH}_{4}$ in the sampled rivers/streams are $0.645 \mathrm{mg} / \mathrm{L}, 1.006 \mathrm{mg} / \mathrm{L}$ and $3.189 \mathrm{mg} / \mathrm{L}$ respectively, which are higher than other rivers/streams in the world based upon literature cited in Markich and Brown [11] and Zhang et al. [18]. For heavy metals, the total average of $\mathrm{Cu}, \mathrm{Zn}$, $\mathrm{Pb}, \mathrm{Cd}$ and $\mathrm{Ni}$ are $8.80 \mu \mathrm{g} / \mathrm{L}, 79.79 \mu \mathrm{g} / \mathrm{L}, 6.34 \mu \mathrm{g} / \mathrm{L}, 0.61 \mu \mathrm{g} / \mathrm{L}$ and $7.00 \mu \mathrm{g} / \mathrm{L}$ respectively, which are also higher than those rivers in other countries, based upon the literature cited in Audry et al. [1], Gueguen et al. [7], Markich and Brown [11]. These results may highlight the problems of excessive nutrients and metals in HK rivers.

The extent of variation among the various water-quality determinands is also different. Table 1 gives the relative standard deviation (RSD) of each determinand. It is found that the RSD for the majority of physical elements 
$(6.691 \% \sim 277.618 \%)$ is lower than that of most nutrients $(123.173 \% \sim$ $290.762 \%)$, aggregate organics $(178.143 \% \sim 231.869 \%)$ and heavy metals (159.183\% 1172.461\%). This result confirms that the concentrations of these water-quality determinands are highly variable among the inland rivers and streams, even though the land area of HK is not large. It is believed that this variability may reflect anthropogenic and other impacts, which are discussed in the following section.

Table 1: Descriptive statistics of physiochemical variables among 82 monitoring stations in $\mathrm{HK}$.

\begin{tabular}{|c|c|c|c|c|c|c|}
\hline Element group & $\begin{array}{c}\text { Physiochemical } \\
\text { elements }\end{array}$ & $\begin{array}{c}\text { Sampling } \\
\text { number }\end{array}$ & $\begin{array}{c}\text { Geometric } \\
\text { mean }\end{array}$ & $\begin{array}{l}\text { Arithmetic } \\
\text { mean }\end{array}$ & $\begin{array}{c}\text { Std. } \\
\text { Deviation }\end{array}$ & \begin{tabular}{|c} 
Relative \\
S.D \\
(RSD, in \\
$\%)$ \\
\end{tabular} \\
\hline \multirow{9}{*}{$\begin{array}{l}\text { Physical } \\
\text { elements }\end{array}$} & $\mathrm{Cl}(\mathrm{mg} / \mathrm{L})$ & 3927 & 210.640 & 2502.081 & 4354.071 & 174.018 \\
\hline & $\mathrm{TS}(\mathrm{mg} / \mathrm{L})$ & 5675 & 490.156 & 3801.625 & 8210.261 & 215.967 \\
\hline & $\mathrm{EC} \mu \mathrm{S} / \mathrm{cm})$ & 5675 & 608.166 & 5015.756 & 10282.71 & 205.008 \\
\hline & $\mathrm{Sal}(\mathrm{mg} / \mathrm{L})$ & 3950 & 0.751 & 4.312 & 7.332 & 170.033 \\
\hline & $\mathrm{pH}$ & 5675 & 7.495 & 7.512 & 0.503 & 6.691 \\
\hline & $\mathrm{DO}(\mathrm{mg} / \mathrm{L})$ & 5675 & 6.961 & 7.473 & 2.24 & 29.968 \\
\hline & $\mathrm{DO}(\%)$ & 5675 & 84.735 & 90.739 & 26.49 & 29.194 \\
\hline & $\operatorname{Temp}\left({ }^{\circ} \mathrm{C}\right)$ & 5675 & 24.296 & 24.722 & 4.423 & 17.89 \\
\hline & Flow $(\mathrm{L} / \mathrm{s})$ & 3338 & 0.059 & 0.19136 & 0.531 & 277.618 \\
\hline \multirow{6}{*}{ Nutrients } & & & & & & 290.762 \\
\hline & $\mathrm{PO}_{4}(\mathrm{mg} / \mathrm{L})$ & 5424 & 0.129 & 0.645 & 1.711 & 265.304 \\
\hline & $\mathrm{TKN}(\mathrm{mg} / \mathrm{L})$ & 5449 & 1.017 & 4.338 & 10.426 & 240.312 \\
\hline & $\mathrm{NO}_{3}(\mathrm{mg} / \mathrm{L})$ & 5520 & 0.037 & 1.006 & 1.24 & 123.173 \\
\hline & $\mathrm{NO}_{2}(\mathrm{mg} / \mathrm{L})$ & 5061 & 0.499 & 0.158 & 0.367 & 232.791 \\
\hline & $\mathrm{NH}_{4}(\mathrm{mg} / \mathrm{L})$ & 5441 & 0.401 & 3.189 & 8.432 & 264.394 \\
\hline \multirow{3}{*}{$\begin{array}{l}\text { Aggregate } \\
\text { organics }\end{array}$} & $\mathrm{COD}(\mathrm{mg} / \mathrm{L})$ & 5335 & 13.716 & 25.368 & 46.602 & 183.706 \\
\hline & $\mathrm{BOD}(\mathrm{mg} / \mathrm{L})$ & 4031 & 5.514 & 13.566 & 31.456 & 231.869 \\
\hline & TOC (mg/L) & 5311 & 4.096 & 6.854 & 12.21 & 178.143 \\
\hline \multirow{9}{*}{ Heavy metals } & $\mathrm{Zn}(\mu \mathrm{g} / \mathrm{L})$ & 4843 & 32.897 & 79.787 & 523.905 & 656.627 \\
\hline & $\mathrm{Pb}(\mu \mathrm{g} / \mathrm{L})$ & 3751 & 2.918 & 6.344 & 20.487 & 322.953 \\
\hline & $\mathrm{Ni}(\mu \mathrm{g} / \mathrm{L})$ & 3081 & 3.503 & 6.998 & 17.4 & 248.652 \\
\hline & $\operatorname{Mn}(\mu g / L)$ & 5215 & 102.251 & 191.045 & 385.838 & 201.962 \\
\hline & $\mathrm{Fe}(\mu \mathrm{g} / \mathrm{L})$ & 5454 & 345.351 & 613.587 & 976.726 & 159.183 \\
\hline & $\mathrm{Cu}(\mu \mathrm{g} / \mathrm{L})$ & 4696 & 4.426 & 8.797 & 23.826 & 270.828 \\
\hline & $\mathrm{Cr}(\mu \mathrm{g} / \mathrm{L})$ & 1783 & 2.471 & 3.485 & 9.639 & 276.584 \\
\hline & $\mathrm{Cd}(\mu \mathrm{g} / \mathrm{L})$ & 1896 & 0.204 & 0.344 & 0.608 & 176.45 \\
\hline & $\mathrm{Al}(\mu \mathrm{g} / \mathrm{L})$ & 4609 & 157.889 & 450.907 & 5286.709 & 1172.461 \\
\hline
\end{tabular}

\subsection{Factor Analysis on water-quality determinands}

Factor analysis has been carried out to examine the inter-relationship among the water-quality determinands. All 27 parameters were included in the preliminary stage of analysis, but the Measures of Sampling Adequacy (MSA) indicated the need for the variable selection, which reduced the dataset to 17 determinands (Table 2). The factor analysis shows good results, explaining $85.881 \%$ of the total variance of the whole dataset. Reflected by the extracted communities, 
these factors can solve $59.20 \% \sim 98.94 \%$ of variance in each variable. Finally, the KMO test and Barlett's Test of Sphericity confirm that the standardized dataset is adequate for conducting factor analysis $(\mathrm{KMO}=0.755)$ and subject to the normal distribution (Approx Chi-sq $=3284.269$, $\mathrm{p}$-value $=0.000$ ).

The results of the factor analysis are summarized in table 2. Factor 1, explaining $43.192 \%$ of factor variance, has a high factor loading of TKN, TP, $\mathrm{PO} 4, \mathrm{NH} 4, \mathrm{TOC}, \mathrm{COD}$, and $\mathrm{BOD}_{5}$. Factor 2 , explaining $26.318 \%$ of variance, includes Sal, COND, Cl. The third and fourth factors, accounting for $10.270 \%$ and $6.100 \%$ of factor variance, contain $\mathrm{Al}, \mathrm{Pb}, \mathrm{Cr}, \mathrm{Mn}, \mathrm{Zn}$.

Table 2: $\quad$ Factor analysis result of 17 water-quality determinands on four factors after Varimax rotation with Kaiser Normalization (Boldfaced values represent strong loadings).

\begin{tabular}{|c|c|c|c|c|}
\hline & \multicolumn{4}{|c|}{ Component } \\
\hline & 1 & 2 & 3 & 4 \\
\hline TKN & .965 & -.073 & .091 & .121 \\
\hline $\mathrm{TP}$ & .958 & -.107 & -.009 & .051 \\
\hline $\mathrm{NH}_{4}$ & .951 & -.094 & .065 & .114 \\
\hline TOC & .937 & .002 & .220 & .139 \\
\hline $\mathrm{PO}_{4}$ & .932 & -.109 & -.081 & .011 \\
\hline COD & .915 & .216 & .219 & .127 \\
\hline BOD5 & .817 & -.047 & .286 & .102 \\
\hline DOmg/L & -.776 & -.297 & -.161 & -.291 \\
\hline $\mathrm{SAL}$ & -.013 & .995 & .003 & -.011 \\
\hline COND & .000 & .994 & .007 & -.004 \\
\hline $\mathrm{Cl}$ & -.009 & .993 & .008 & -.007 \\
\hline TS & -.023 & .992 & .001 & -.015 \\
\hline $\mathrm{Al}$ & .192 & .009 & .917 & .037 \\
\hline $\mathrm{Pb}$ & .300 & -.173 & .748 & .297 \\
\hline $\mathrm{Cr}$ & -.029 & .514 & .613 & -.073 \\
\hline $\mathrm{Mn}$ & .151 & .093 & .003 & .749 \\
\hline $\mathrm{Zn}$ & .153 & -.141 & .152 & .730 \\
\hline Eigenvalues & 7.343 & 4.474 & 1.746 & 1.037 \\
\hline$\%$ of Variance & 43.192 & 26.318 & 10.270 & 6.100 \\
\hline Cumulative $\%$ & 43.192 & 69.510 & 79.781 & 85.881 \\
\hline
\end{tabular}

Factor 1 is related to nutrient and organic contamination. In unpolluted rivers, the concentration of $\mathrm{PO} 4$ and $\mathrm{NH} 4$ are very low $(<0.020 \mathrm{mg} / \mathrm{L}$ and $<0.2 \mathrm{mg} / \mathrm{L}$ respectively; Chapman and Kimstach [3]); therefore, very high concentrations of $\mathrm{N}$ and $\mathrm{P}$ may indicate that there are excessive nutrients coming from anthropogenic inputs, including agricultural runoff with fertilizers, livestock wastes and municipal wastes. Similarly, in rivers with high organic loading (one example is TOC), the biodegradation of organic matter by bacteria or chemical oxidants will consume dissolved oxygen; therefore, in sewage or industrial effluents, the TOC, BOD and COD may be over $100 \mathrm{mg} / \mathrm{L}$ while DO may reduce to $0 \%$ (Chapman and Kimstach [3]). 
Table 3: The classification of Hong Kong rivers/streams and their stations based on Q-mode factor analysis.

\begin{tabular}{|c|c|c|}
\hline Group & Stations & River or stream \\
\hline $\begin{array}{c}1 \\
(10)^{*}\end{array}$ & $\begin{array}{l}\text { KT1, KT2, YL3, YL4, TN1, RB2, } \\
\text { RB3, IN1, FVR1, TSR1 }\end{array}$ & $\begin{array}{l}\text { Kam Tin River, Lower Yuen Long Creek, Upper } \\
\text { Tuen Mun River, Fariview Park Nullah, Lower } \\
\text { River Beas, Lower River Indus, Lower Tin Shui } \\
\text { Wai Nullah }\end{array}$ \\
\hline $\begin{array}{c}2 \\
(14)^{*}\end{array}$ & $\begin{array}{l}\text { GR1, GR2, YL1, YL2, KN1, } \\
\text { KN2, KN3, KN4, KN5, KN7, } \\
\text { JR6, JR3, RB1, DB6 }\end{array}$ & $\begin{array}{l}\text { River Ganges, Upper Yuen Long Creek, Kai Tak } \\
\text { Nullah, Tsueng Lan Shue River, Upper River } \\
\text { Beas, Ngau Hom Ha Stream }\end{array}$ \\
\hline $\begin{array}{c}3 \\
(14)^{*}\end{array}$ & $\begin{array}{l}\text { IN2, GR3, KW3, TN2, TN3, TN4, } \\
\text { TN5, TR12C, TR12E, TSR2, } \\
\text { TR17, TR19, TR19A, TR19C }\end{array}$ & $\begin{array}{l}\text { Middle River Indus, Upper River Ganges, Kau } \\
\text { Wa Keng Stream, Tuen Mun River, Tin Shui Wai } \\
\text { Nullah, Middle Tai Po Kau, Fo Tan Nullah, Tin } \\
\text { Sum Nullah, Upper Tin Shui Wai Nullah }\end{array}$ \\
\hline $\begin{array}{c}4 \\
(43)^{*}\end{array}$ & $\begin{array}{l}\text { AN1, AN2, DB1, DB2, DB3, } \\
\text { DB5, DB6, DB8, IN3, JR11, KY1, } \\
\text { MW1, MW2, MW3, MW4, MW5, } \\
\text { TC1, TC2, TC3, TN6, TR4, TR6, } \\
\text { TR12B, TR12D, TR12, TR12G, } \\
\text { TR12H, TR12I, TR13, TR14, } \\
\text { TR17L, TR19I, TR23A, TR23L, } \\
\text { TW1, TW2, TW3, PR1, PR2, } \\
\text { PR5, PR6, PR7, PR8 }\end{array}$ & $\begin{array}{l}\text { Pai Min Kok Stream, Tai Shui Hang, Tsang Kok, } \\
\text { Pak Nai, Sheung Pak Nai stream, Sha Kok Mei, } \\
\text { Ho Chung and Tai Chung Hau Stream, Tung } \\
\text { Chung River, Mui Wo River, Upper Tai Po Kau } \\
\text { river, Siu Lek Yuen Nullah, Kwun Yam Stream, } \\
\text { Sam Dip Tam Stream }\end{array}$ \\
\hline
\end{tabular}

Due to the problem of missing value, the factor scores for TR12F cannot be calculated.

${ }^{*}$ Number of stations

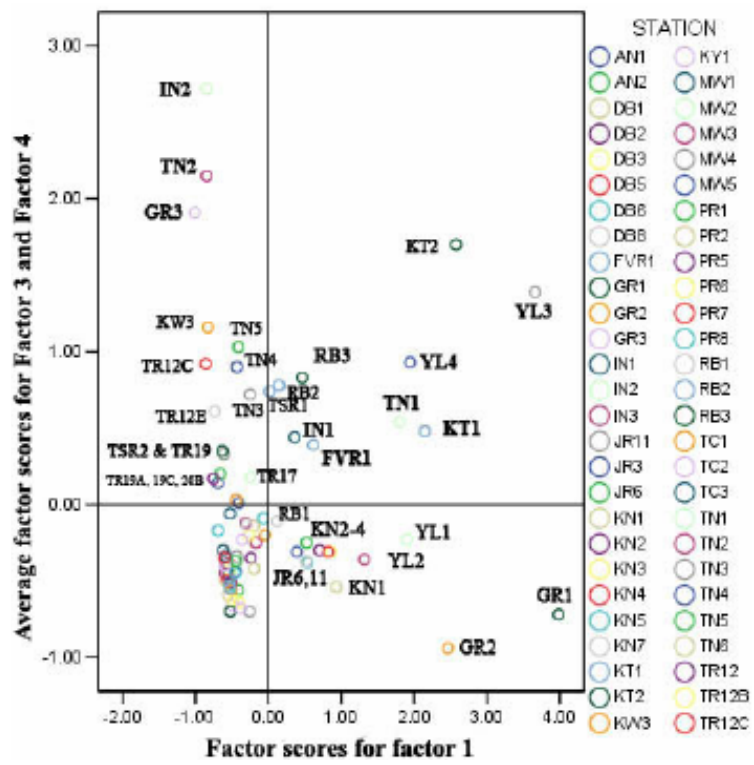

Figure 1: The classification and factor scores of 82 river monitoring stations in Hong Kong. 
Factor 2 may indicate the influence of seawater through marine aerosol deposition or seawater intrusion. Compared with river water, seawater has the following distinctive characteristics: strong ionic strength with high total dissolved solids (TDS) and COND (>1 mS/cm), high salinity with abundant $\mathrm{Na}$ and $\mathrm{Cl}$. Furthermore, estuarine reaches which receive sediment and solids from both river deposits and tidal mixing particles, usually have higher total solids (TS) concentrations (Eisma [5]). Therefore, rivers or aquifers affected by seawater may show certain characteristics/endmembers of seawater. However, these endemembers are not enough to 'certify' the marine influences, because $\mathrm{Cl}$ and TS may also come from the primary sewage treatment plants which apply Ferric Chloride for waste removal (DSD [4]). Other determinands or indicators like Sodium $(\mathrm{Na}) / \mathrm{Cl}, \mathrm{Cl} /$ Iodine (I) may need to be adopted to confirm the influences of seawater (Sin et al. [15]), but they are not included in the HKEPD's dataset.

Finally, factors 3 and 4 are composed of 5 types of heavy metals, indicating the potential of heavy metal contamination. Similar to nutrient and organic wastes, the concentration of heavy metals is low in unpolluted rivers $(0.1-0.001$ $\mu \mathrm{m})$ unless they are affected by domestic or industrial activities (Chapman and Kimstach [3]). For example, $\mathrm{Cu}, \mathrm{Zn}, \mathrm{Pb}, \mathrm{Ni}, \mathrm{Cd}, \mathrm{Cr}$ are common materials in textile dyes, electroplating, galvanizing battery manufacture and plastic fabrication, which are also popular types of industry in HK (Zhou et al. [19]). To sum up, factors 1,3 and 4 are mostly related to the anthropogenic inputs of chemical elements to the streams/rivers.

To examine the spatial controls of the anthropogenic influence governing the distribution of these determinands, the regression factor scores based on the results of the factor analysis are calculated for each individual monitoring site. Since factor 2 (the marine influences) may be caused by natural influences tidal effects, its factor scores are omitted. Also, as both the third and fourth factors of table 2 reflect the same type of human impact (heavy metal contamination), their factor scores are averaged. As a result, four groups of rivers and associated factor scores are identified, which are given in table 3 and shown in figure 1 . The final groupings are discussed below.

\section{Group 1: Multiple types of contamination}

In this group, 10 river stations have positive factor scores for factor 1 and average scores for both factors 3 and 4, indicating that they are affected by multiple types of contamination (nutrient, aggregate organic and heavy metal contamination). These stations also have higher concentrations of most nutrients, aggregate organics and some heavy metals. In HK, they are mainly located at the edge of newtowns that receive diverse sources of contaminants.

\section{Group 2: High nutrient and organic values, less heavy metal contamination}

In this group, 14 river stations have positive scores for factor 1 but negative average scores for both factors 3 and 4 . These results indicate that the dominating types of human impact in these stations are nutrient and organic contamination rather than heavy metal contamination; some peak concentrations 
of nutrients and aggregate organics can be observed in the monitoring stations of this group. Most of these stations are found in rural area or old-developed downtown of Hong Kong.

\section{Group 3: High heavy metal contamination, lower nutrient and organic contamination}

In this group, 14 river stations have positive average scores for both factors 3 and 4 but negative scores for factor 1 . These results mean that heavy metal contamination is more significant than nutrient and organic contamination at these monitoring stations, and the peak concentration of heavy metals may exist at these monitoring sites/rivers. Nearly all of these stations are located near to the factory areas and/or heavy traffic roads.

\section{Group 4: Less-contaminated rivers}

In this group, 43 river stations do not reveal the influences of nutrient, organic and heavy metal contamination, or these influences are masked by other factors such as seawater or geological minerals. All of them have negative average scores for both factor 1, factors 3 and 4. These streams/rivers, which have the lowest concentrations of nutrients, aggregate organics and heavy metals, are mainly found inside the remote area or country park of HK.

\section{Conclusion}

Although the land area in HK is small $\left(1102 \mathrm{~km}^{2}\right)$, the concentration of physical, nutrient, aggregate organics and heavy metal elements vary greatly among different watercourses. The factor analysis identifies marine and anthropogenic influences upon the interrelationship of water-quality determinands, and classifies the local watercourses into four groups: some of them either have nutrient and organic contamination (Group 2) or heavy metal contamination (Group 3), while the others either suffer multiple types of contamination (Group 1) or have a low contamination problem (Group 4). The spatial location of the sites in each group supports the interpretation of the spatial controls upon the groups.

\section{Acknowledgements}

The authors thank the Hong Kong Environmental Department for providing water-quality data of this study. The efforts contributed by Miss Y.C. Lau (dataset manipulation) and Miss P.S. Wong (manuscript review) are greatly appreciated. The Hui Oi-Chow Trust financial support is acknowledged.

\section{References}

[1] Audry, S., Schafer J., Blanc, G., Bossy, C. \& Lavaux G. (2004). Anthropogenic components of heavy metal $(\mathrm{Cd}, \mathrm{Zn}, \mathrm{Cu}, \mathrm{Pb})$ budgets in the 
Lot-Garonne fluvial system (France). Applied Geochemistry, 19(5), pp. 769-786.

[2] Berner E. K.\& Berner R. A. (1987). The global water cycle : geochemistry and environment: Englewood Cliffs, N.J. : Prentice-Hall, New York.

[3] Chapman D.\& Kimstach. V. (1996). Chapter 3- Selection of water quality determinands. In D. Chapman (Ed.), Water quality assessments : a guide to the use of biota, sediments and water in environmental monitoring, pp. 59125. London: E \& FN Spon.

[4] Drainage Service Department (DSD). (10 June 2005). Sewerage Sewerage Strategy (online). Retrieved 02 Aug 2005, from http://www.dsd.gov.hk/sewerage/sewerage_strategy/index.htm.

[5] Eisma, D. (1993). Suspended matter in the aquatic environment. Berlin: Springer-Verlag.

[6] Environmental Protection Department (EPD). (2004). River Water Quality in Hong Kong in 2003. Hong Kong: Monitoring Section, Water Policy and Planning Group, Environmental Protection Department, The Government of the HKSAR.

[7] Gueguen C., Dominik. J., Pardos M., Benninghoff C. \& Thomas R.L. (2000). Partition of metals in the Vistula River and in effluents from sewage treatment plants in the region of Cracow (Poland). Lakes \& Reservoirs: Research and Management, 5(2), pp. 59-66.

[8] Helsel D.R.\& Hirsch. D. R. (1992). Statistical methods in water resources: Amsterdam : Elsevier.

[9] Lee W.S.E., Hau. C. H. B.\& Corlett R. T. (2005). Natural regeneration in exotic tree plantations in Hong Kong, China. Forest Ecology and Management, 212(1-3), pp. 358-366.

[10] Li H.E., Lee. J. H. W., Koenig A.\& Jayawardena A.W. (2003). Nutrient load estimation of nonpoint source contamination for Hong Kong Region. Diffuse Contamination Conference Dublin, ECS 5: Management.

[11] Markich S J.\& Brown. P. L. (1998). Relative importance of natural and anthropogenic influences on the fresh surface water chemistry of the Hawkesbury-Nepean River, south-eastern Australia. The Science of The Total Environment, 217, pp. 201-230.

[12] Meybeck, M. (2003). Global analysis of river systems: from Earth system controls to Anthropocene syndromes. Philos. Trans. R. Soc. Lond. B. Biol. Sci, 358(1440), pp. 1935-1955.

[13] Peart, M. R. (1997). Human impact upon sediment in rivers: some examples from Hong Kong. Human Impact on Erosion and Sedimentation (Proceedings of Rabat Symposium S6, April 1997). IAHS Publ. 245, pp. 111-118.

[14] Pekey H., Karakas. D.\& Bakoglu M. (2004). Source apportionment of trace metals in surface waters of a polluted stream using multivariate statistical analyses. Marine Contamination Bulletin, 49, pp. 809-818.

[15] Sin S. N., Chua H., Lo W.\& Ng L.M. (2001). Assessment of heavy metal cations in sediments of Shing Mun River, Hong Kong. Environment International, 26(5-6), pp. 297-301. 
100 Water Pollution VIII: Modelling, Monitoring and Management

[16] United Nations Economic and Social Commission for Asia and the Pacific, (UNESCAP) (1990). Water quality monitoring in the Asian and Pacific region. New York: United Nations Economic and Social Commission for Asia and the Pacific.

[17] Woitke P., Wellmitz J., Helm D., P. Kube, P. Lepom \& P. Litheraty. (2003). Analysis and assessment of heavy metal contamination in suspended solids and sediments of the river Danube. Chemosphere, 51(8), pp. 633-642.

[18] Zhang J., Yu. Z-G., Wang J-T., Ren J-L., Chen H-T., Xiong H.\& Dong LX., Xu W-Y. (1999). The Subtropical Zhujiang (Pearl River) Estuary: Nutrient, Trace Species and Their Relationship to Photosynthesis. Estuarine, Coastal and Shelf Science, 49(3), pp. 385-400.

[19] Zhou, H. Y., Cheung, R. Y. H. , Chan K. M. \& Wong, M. H. (1998). Metal concentrations in sediments and tilapia collected from inland waters of Hong Kong. Water Research, 32(11), pp. 3331-3340. 